\title{
Evaluation of Mechanical Properties of Samples Printed by FDM Method
}

\author{
Miloslav Linda ${ }^{1}$, Miroslav Müller ${ }^{2}$, Rostislav Chotěborský $^{2}$ \\ ${ }^{1}$ Faculty of Engineering, Department of Electrical Engineering and Automation, Czech University of Life Sciences in \\ Prague. Kamýcka 129, 16521 Praha - Suchdol. Czech Republic. E-mail: linda@tf.czu.cz. \\ ${ }^{2}$ Faculty of Engineering, Department of Material Science and Manufacturing Technology, Czech University of Life Sci- \\ ences in Prague. Kamýcka 129, 16521 Praha - Suchdol. Czech Republic. E-mail: muller@tf.czu.cz, \\ choteborsky@tf.czu.cz.
}

To ensure optimal conditions of instruction in technical subjects it is fundamental to have laboratory trainings where students learn methods of the material measuring and they get pieces of knowledge about a test equipment. Financial cost of samples leads to minimizing laboratory trainings. It can be solved by fused deposition modelling (FDM). The aim of the research was to test a possibility to use test samples made by means of FDM method for an implementation within the practical training. Within the research two standard materials determined for FDM (that means ABS plastic and PLA) were used. Test samples were made / printed by a printer EASY3DMAKER with using a software G3DMAKER. Test of an abrasive wear, a hardness Shore D measurement, a tensile strength and an impact strength were performed for verifying a functionality of the test samples printed by FDM method for laboratory experiments.

Keywords: laboratory training, testing, research, fused deposition modeling

Acknowledgement

Supported by Internal grant agency of Faculty of Engineering, Czech University of Life Sciences in Prague no. 31200/1312/3125.

\section{References}

[1] NÁPRSTKOVÁ, N. (2011). Using of Catia V5 Software for Teaching at Faculty of Production Technology and Management. In: Proceedings from 10th International Scientific Conference Engineering for Rural Development, Volume 10, pp. 554 -557, Jelgava, Latvia University of Agriculture, Faculty of Engineering.

[2] NÁPRSTKOVÁ, N., NÁPRSTEK, V., HOLEŠOVSKÝ, F. (2008). Nettings of Students to the Grinding Process Monitoring, In: Engineering for Rural Development, pp. 296 -299, Latvia University of Agriculture Faculty of Engineering.

[3] NOVAK-MARCINCIN, J., FECOVA, V., BARNA, J., JANAK, M., NOVAKOVA- MARCINCINOVA, L. (2013). Using of the Virtual Reality Application with the Scanning Device Kinect for Manufacturing Processes Planning, In: Manufacturing technology, Vol. 13. No. 2 pp. 215 - 219.

[4] MÜLLER, M., VALÁŠEK, P. (2012). Abrasive wear effect on Polyethylene, Polyamide 6 and polymeric particle composites, In. Manufacturing technology, Vol. 12, No. 12, pp. 55 - 59.

[5] NOVÁK, M. (2012). Surfaces with high precision of roughness after grinding. In: Manufacturing technology, Vol. 12, No.12, pp. $66-70$.

[6] NOVÁK, M. (2011). Surface quality of hardened steels after grinding. In: Manufacturing technology, Vol. 11, No. 11, pp. 55 - 59.

[7] NESLUŠAN, M., ROSIPAL, M., KOLAŘIK, K., OCHODEK, V. (2012). Application of barkhausen noise for analysis of surface integrity after hard turning. In: Manufacturing technology, vol. 12, no. 11, pp. 60 - 65.

[8] HOLEŠOVSKÝ, F., NÁPRSTKOVÁ, N., NOVÁK, M. (2012). GICS for grinding process optimization, In: Manufacturing technology, Vol. 12, No. 11, pp. 22 - 26.

[9] ČSN 62 1466: 1993. Rubber, determination of abrasion resistance using a rotating cylindrical drum device. Prague: Federal office for standard and measuring, $1993.12 \mathrm{p}$.

[10] MÜLlER, M., VALÁŠEK, P. (2012). Abrasive wear effect on Polyethylene, Polyamide 6 and polymeric particle composites, In: Manufacturing technology, Vol. 12, No. 12, pp. 55 - 59.

[11] ČSN EN ISO 868: 2003. Plastics and ebonite - Determination of indentation hardness by means of durometr (Shore hardness). Czech Standard Institution, Prague, 2003. 10 p.

[12] ČSN EN ISO 3167 (1997): Plastics - Multipurpose test specimens. Czech Standard Institute, Prague. 
[13] ČSN EN ISO 527-1 (1997): Plastics - Determination of tensile properties - Part 1: General principles. Czech Standard Institute, Prague.

[14] VALÁŠEK, P., MÜLLER, M. (2013). Polymeric composite based on glass powder - usage possibilities in agrocomplex. In: Scientia Agriculturae Bohemica, Vol. 44, No. 2, pp. 107 - 112.

[15] VALÁŠEK, P., MÜLLER, M. (2013). Composite based on hard-cast irons utilized on functional areas of tools in agrocomplex. In: Scientia Agriculturae Bohemica, Vol .44, No. 3, pp. 172 - 177.

Paper number: M201411

Copyright @ 2 2014. Published by Manufacturing Technology. All rights reserved. 